\title{
En mann i 50-årene med feber, hoste og anuri
}

\author{
Akutt nyresvikt er en alvorlig tilstand som kan ha mange årsaker. \\ Rask diagnostikk og korrekt behandling er viktig for å hindre alvorlige \\ komplikasjoner og bedre prognosen.
}

Se kommentar side 1624

\author{
Per Olav Rui \\ per.olav.rui@helse-bergen.no \\ Medisinsk avdeling \\ Haukeland universitetssykehus \\ Einar Svarstad \\ Medisinsk avdeling \\ Haukeland universitetssykehus \\ og \\ Institutt for Indremedisin \\ Universitetet i Bergen

\section{Leif Bostad} \\ Avdeling for patologi \\ Haukeland universitetssykehus \\ og \\ Institutt for patologi \\ Universitetet i Bergen

\section{Bjørn Egil Vikse} \\ Medisinsk avdeling \\ Haukeland universitetssykehus \\ Institutt for Indremedisin \\ Universitetet i Bergen
}

En mann i 50-årene oppsøkte lege på grunn av tørrhoste, slapphet og feberi to uker. Bortsett fra en episode med nyrestein var pasienten tidligere frisk. Han brukte ingen medikamenter og var i full jobb. Blodprøver viste $C$-reaktivt protein (CRP) $224 \mathrm{mg} / \mathrm{l}(<5 \mathrm{mg} / \mathrm{ll}$, normal leukocyttkonsentrasjon og differensialtelling, hemoglobin 11,1 g/100 $\mathrm{ml}(13,4-17 \mathrm{~g} / 100 \mathrm{ml})$, trombocytter $556 \cdot 10^{9} / \mathrm{l} \quad\left(145-348 \cdot 10^{\%} / \mathrm{l}\right)$, kreatinin $102 \mu \mathrm{mol} / \mathrm{l}(60-105 \mu \mathrm{mol} / \mathrm{l})$, eGFR $>60 \mathrm{ml} / \mathrm{min} / 1,73 \mathrm{~m}^{2}$ (> $60 \mathrm{ml} / \mathrm{min} / 1,73 \mathrm{~m}^{2}$ ) Han fikk forskrevet erytromycin på mistanke om luftveisinfeksjon. Fem dager senere oppsøkte han på ny lege pga. manglende bedring samt at han siste døgn kun hadde observert noen dråper urin til tross for et væskeinntak på mer enn 1 l daglig. Han var kvalm, hadde dårlig appetitt, vedvarende feber og følte seg slapp. Ved klinisk undersøkelse var blodtrykket 80/ $60 \mathrm{~mm} \mathrm{Hg}$. Legevaktlege fant bankeømhet over nyrelosjene bilateralt, men ingen dempning over urinblæren. Han ble innlagt i medisinsk avdeling med spørsmål om nyresvikt pga. lav diurese og bankeømhet over nyrelosjene, og uavklart infeksjon.
Med lavt blodtrykk, vedvarende feber og kvalme kunne væskeunderskudd (prerenal nyresvikt) være en årsak til oliguri/anuri. Hypotensjon og feber kunne gi mistanke om sepsis. Akutt nyresvikt er vanlig ved sepsis pga. renal hypoperfusjon sekundært til sympatikusmediert vasokonstriksjon og hypotensjon. Endotoksiner og økt intraabdominalt trykk kan også bidra til nyreskade i forbindelse med sepsis $(1,2)$. Pasienten hadde fått erytromycin, og antibiotika kan gi akutt interstitiell nefritt og akutt nyresvikt $(3,4)$. Denne tilstanden ledsages ofte av eosinofili og utslett som ledd i en allergisk reaksjon på antibiotika. Det er imidlertid ikke vanlig med anuri ved akutt interstitiell nefritt.

Ved innleggelsen var blodtrykket 95/58 mm $\mathrm{Hg}$, puls 67/min. Han var afebril, men slapp. Ultralydundersøkelse av blære viste tom urinblære. Han var ikke bankeøm over nyrelosjene og det var ingen fremmelyder over lungene. Arteriell blodgass viste $\mathrm{pH} \mathrm{7,44}$ (7,36-7,44), $\mathrm{pO}_{2} 12,2 \mathrm{kPa}(11-13 \mathrm{kPa}), \mathrm{pCO}_{2}$ $3,70 \mathrm{kPa}(4,50-6,10 \mathrm{kPa})$, bikarbonat 18,6 $\mathrm{mmol} / \mathrm{l}$ (22-26 mmol/l), baseunderskudd $4,8 \mathrm{mmol} / \mathrm{l}(-3,+3)$ og kalium $5,3 \mathrm{mmol} / \mathrm{l}$ (3,5-5,0 mmol/l). Etter undersøkelse i akuttmottak var det fortsatt mistanke om sepsis, og behandling ble startet med cefotaksim intravenøst og intravenøs væske. Blodkultur ble tatt før oppstart med cefotaksim. Det ble lagt inn blærekateter, men det var ingen urinproduksjon og man fikk derfor ikke utført urinundersøkelser. Etter hvert forelå det innkomstblodprøver som viste kreatinin $835 \mu \mathrm{mol} / \mathrm{l}(60-105 \mu \mathrm{mol} / \mathrm{l}), \mathrm{kar}$ bamid $31 \mathrm{mmol} / \mathrm{l}(3,5-8,1 \mathrm{mmol} / \mathrm{l})$, senkning $132 \mathrm{~mm} / \mathrm{t}(1-20 \mathrm{~mm} / \mathrm{t})$, CRP $325 \mathrm{mg} / \mathrm{l}$, leukocytter $17,6 \cdot 10^{9} / 1\left(3,5-11,0 \cdot 10^{9} / 1\right)$ derav nøytrofile $14,8 \cdot 10^{9} /\left(1,7-8,2 \cdot 10^{9} / l\right)$. Røntgen thorax viste litt pleuravæske på venstre side, men ingen lungefortetninger.

Pasienten hadde akutt nyresvikt med respiratorisk kompensert metabolsk acidose og hyperkalemi. Hyperkalemien var beskjeden i lys av pasientens anuri, men bidragende årsaker kunne være kort sykehistorie og lite matinntak (kvalme) og dermed lite kaliuminntak. Det forelå betydelig forhøyet CRP uten sikkert infeksjonsfokus. Han hadde vedvarende anuri selv etter 51 væsketilførsel intravenøst etter innkomst, med normalisering av blodtrykket. Ultralydundersøkelse av nyrene er viktig i tidlig diagnostikk både av primær nyresykdom og ved nyreaffeksjon sekundært til andre sykdommer. Hos denne pasienten var undersøkelsen viktig for å utelukke hydronefrose og abscess samt vurdere ekkogenisitet av nyreparenkym, nyrelengde og parenkymbredde.

Ultralydundersøkelse dagen etter innleggelse viste normalt store nyrer med normal parenkymbredde og diffust økt ekkogenisitet i parenkymet bilateralt. Ingen hydronefrose, konkrementer eller ekspansive prosesser ble sett, og ingen lokaliserte hypo- eller hyperekkoiske prosesser i nyrene som kunne gi mistanke om abscess.

Ved akutt nyresvikt av primær renal årsak vil det ultrasonografisk ofte påvises forstørrede nyrer med svullent nyreparenkym med økt størrelse og økt ekkogenisitet på grunn av celleinfiltrasjon i nyrevevet, økt antall sylindre i tubuli, ev. diffuse kalknedslag (nefrokalsinose). Men det kan foreligge normal ekkogenisitet i nyreparenkymet også ved raskt progredierende glomerulonefritt. Ved akutt nyresvikt utløst av dehydrering, medikamenter, sepsis eller kirurgi, vil parenkymet ofte være normoekkoisk, og ikke sjeldent kan nyrene ha et helt normalt utseende. Akutt nyresvikt med hyperekkoisk nyreparenkym og normal eller økt nyrestørrelse skal derfor alltid vekke mistanke om akutt primær nyresykdom, og snarlig diagnostisk nyrebiopsi vil ofte være indisert (5).

Ved innkomst ble det som ledd i utredning av mistenkt primær nyresykdom (glomerulonefritt eller vaskulitt) bestilt ANA, ANCA(antinøytrofile cytoplasmatiske antistoffer), antiGBM lantistoff mot glomerulusbasalmembran), immunglobuliner, C3, C4, AST og antiDNaseB (gruppe A-streptokokker), serumelektroforese, hepatitt $B$-og $C$-serologi.

Disse prøvene besvares som regel først etter noen dager (opptil en uke), men anti-GBM og ANCA kan bestilles som hurtigtester. Hantavirus- serologi ble ikke undersøkt, men er også en aktuell prøve i utredning av akutt nyresvikt i de deler av landet (Oppland, Hedmark, Vest-Agder og Nordland) hvor denne infeksjonen oftest forekommer. 
Ettersom initial utredning og væsketerapi ikke ga holdepunkt for prerenal eller postrenal årsak til pasientens akutte nyresvikt, og ultralydundersøkelse hadde vist hyperekkoiske nyrer, mistenkte man at det kunne foreligge en raskt progredierende glomerulonefritt. Det ble derfor rekvirert hurtigtester på anti-GBM og ANCA.

Betegnelsen raskt progredierende glomerulonefritt blir ofte benyttet for kliniske manifestasjoner som indikerer alvorlig form for glomerulonefritt. De fleste pasientene med dette kliniske bildet har halvmåneglomerulonefritt, som kan gi alvorlig nyresvikt i løpet av få dager og uker. Tilstanden er karakterisert ved glomerulær nekrose med alvorlig skade i glomerulusbasalmembranen hvor betennelsesceller og epiteliale celler danner en halvmåneliknende struktur i Bowmans rom omkring glomerulus (6). Halvmånenefritt kan ses ved Wegeners granulomatose og andre ANCA-assosierte vaskulitter (Churg-Strauss' syndrom, mikroskopisk polyangitt, isolert halvmånenefritt med antimyeloperoksidase (MPO), Goodpastures syndrom (anti-GBM nefritt), lupusnefritt, postinfeksiøs glomerulonefritt, IgA-nefropati og Henoch-Schønleins purpura (6). Ved halvmånenefritt er det viktig med rask behandling for å redusere risiko for irreversibel nyreskade og vedvarende alvorlig nyresvikt (6). Goodpastures syndrom og Wegeners granulomatose kan også gi alvorlige og potensielt livstruende ekstrarenale organmanifestasjoner, og særlig er lungeblødninger (hemoptyse) et alvorlig tegn som krever rask diagnostikk og behandling.

Dagen etter innleggelse forelå svar på antiGBM titer som var positivt, ANCA var negativ. Diagnosen anti-GBM-glomerulonefritt var da overveiende sannsynlig. Pasienten ble henvist til innleggelse av dialysekateter for hemodialyse på grunn av alvorlig nyresvikt med sikker dialyseindikasjon og oppstart av plasmaferesebehandling (plasmautskiftning) for å fjerne anti-GBM-antistoffer.

Ved anti-GBM-glomerulonefritt foreligger antistoffer (anti-GBM-antistoffer) rettet mot NC1-domenet i alfa-3-kjeden i type 4-kollagen i glomerulusbasalmembranen (7). Inntil $40-60 \%$ av pasientene har samtidig alveolær lungeblødning hvor de samme antistoffene angriper basalmembranen $i$ alveolene (6). Klinisk kan pasientene ha tungpust, hoste og hemoptyse. Pasienten vår hadde hatt hoste i lengre tid, men var ikke tungpustet og hadde ikke hatt hemoptyse.

Vi avventet nyrebiopsi initialt fordi vi anså diagnosen anti-GBM-nefritt å være overveiende sannsynlig og valgte å starte behandling for denne tilstanden. Den viktigste komplikasjonen til nyrebiopsi er blødning, og ettersom vi ved plasmautskiftning fjernet koagulasjonsfaktorer samt benyttet intravenøs antikoagulasjon, prioriterte vi
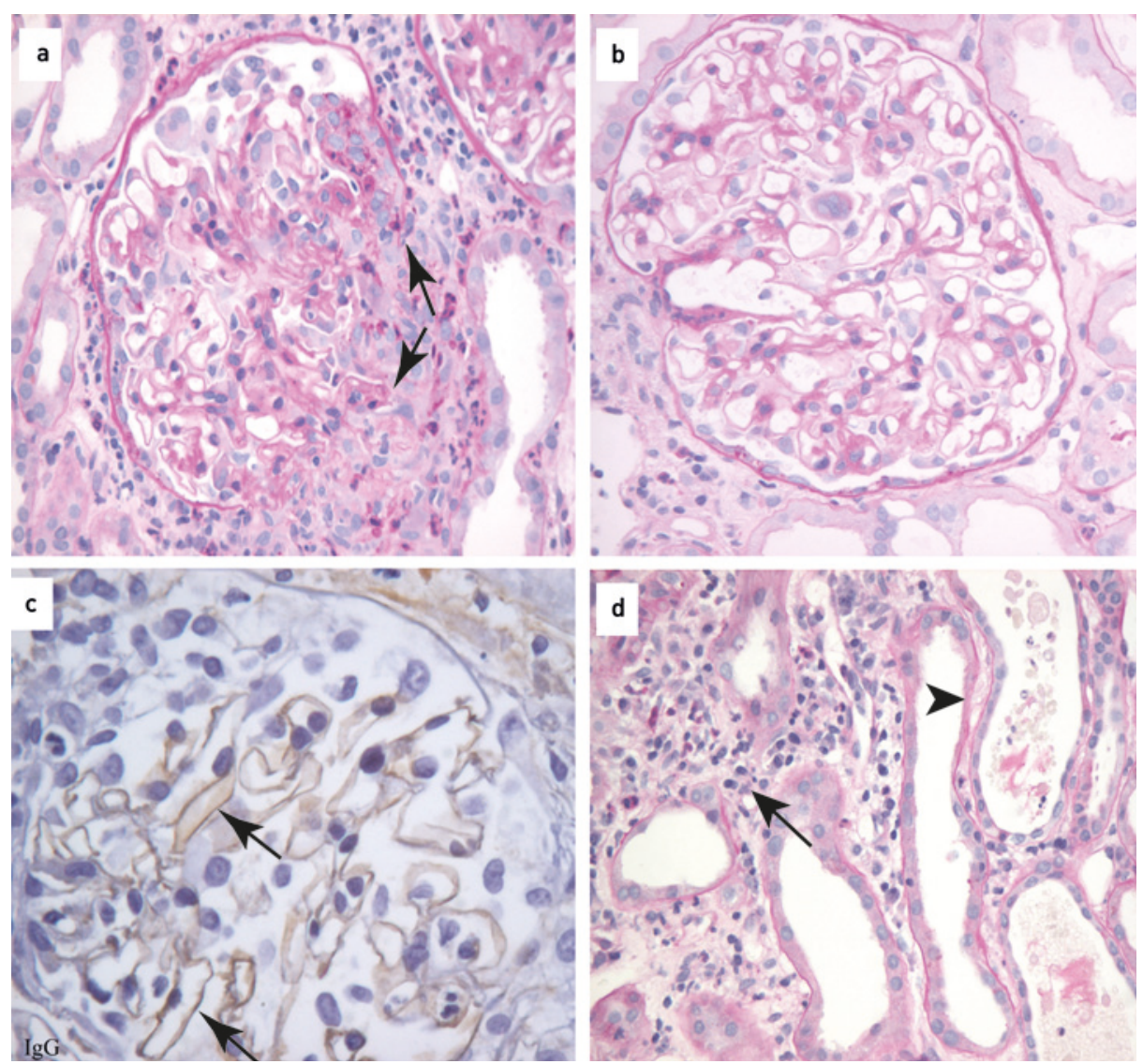

Figur 1 Nyrebiopsi fra pasienten. a) Halvmåne (piler), b) Normal glomerulus, c) Lineært nedslag av IgG (pil)، d) Dilatert tubulus med avflatet epitel (pilhode) og breddeforøket interstitium med betennelseceller (pil)

antatt kausal behandling fremfor diagnostisk nyrebiopsi. Plasmautskiftning gis daglig den første tiden, og avbrudd i denne behandlingen kunne forverret nyreskaden.

Plasmautskiftning ble utsatt til neste dag på grunn av økt blødningsrisiko etter at man ved et uhell hadde truffet a. subclavia før dialysekateteret ble korrekt plassert $i$ $v$. jugularis interna. Pasienten fikk standard immunsuppressiv behandling for anti-GBMglomerulonefritt med høydose steroider Imetylprednisolon intravenøst $1 \mathrm{~g}$ daglig i tre dager, deretter prednisolon peroralt $60 \mathrm{mg}$ dagligl og cytostatika (cyklofosfamid $100 \mathrm{mg}$ peroralt daglig). Det ble også startet med trimetoprim-sulfa én tablett daglig som profylakse mot pneumocystis jirovecii-infeksjon. Påbegynt antibiotikabehandling med cefotaksim ved innkomst ble videreført ettersom alvorlig infeksjon ikke kunne utelukkes og pasienten var betydelig immunsvekket limmunsuppressiver og plasmautskiftning). CRP ble nærmest normal i løpet av fem dager. Etter ti dagers behandling med cefotaksim tilkom clostridiumkolitt, denne ble behandlet med metronidazol, og cefotaksim ble seponert. 12 dager etter innleggelsen var pasienten fremdeles anurisk og det ble tatt nyrebiopsi.

Cefotaksimbehandlingen disponerte for clostridiuminfeksjon, og antibiotika kunne trolig vært seponert noe tidligere. Ettersom pasienten fremdeles var anurisk etter 12 dager, ble det besluttet å utføre nyrebiopsi for å vurdere grad av reversibilitet av nyreskaden. På grunn av blødningsrisiko etter nyrebiopsi ble behandlingsserien med plasmautskiftning avbrutt midlertidig.

Nyrebiopsi viste nekrotiserende glomerulonefritt med halvmåner $i$ fem av åtte glomeruli (fig 1). I tillegg var det uttalte akutte tubulointerstitielle forandringer med ødem, betennelsesceller og tubulær nekrose. Immunhistokjemisk undersøkelse viste sannsynlig lineært nedslag av Ig G langs glomerulære kapillarvegger. Kroniske forandringer Iglomerulær sklerose, tubulær atrofi og interstitiell fibrose), ble ikke påvist. Funnene var forenlige med anti-GBM-glomerulonefritt. Anti-GBM-antistoff-titre var fremdeles høye på dette tidspunktet, og behandlingen hadde ennå ikke fungert med tanke på å fjerne antistoffene.

Ettersom biopsien viste uttalte akutte forandringer var det håp om at nyrefunksjonen ville kunne bedres og at pasienten kunne bli dialysefri med fortsatt aktiv immundempende behandling.

Pasienten fortsatte behandlingen med plasmautskiftning seks dager per uke i tillegg til uendrede doser peroralt cyklofosfamid og 
prednisolon. Tre uker etter oppstart av immunsuppressiv behandling utviklet pasienten behandlingskomplikasjoner som ofte ses ved denne type tilstander. Først tilkom beinmargsvikt, senere cytomegalovirus (CMV)infeksjon. Beinmargssvikt ble behandlet med forbigående seponering av cyklofosfamid, og CMV-infeksjonen ble behandlet med ganciklovir og valganciklovir. Etter sju dagers behandlingspause ble det igjen startet opp med plasmautskiftning og cyklofosfamid i redusert dose (50 mg daglig). Etter fire ukers anuri fikk pasienten urinproduksjon som gradvis økte til normale volum i løpet av én uke. Dialysebehandling kunne avsluttes sju uker etter oppstart.

Pasienten fikk til sammen 29 behandlinger med plasmautskiftning. Anti-GBM-antistoff-konsentrasjonen ble målt to ganger per uke og behandlingen avsluttet først etter at det forelå to negative antistofftiter. Pasienten ble utskrevet fra sykehuset åtte uker etter innleggelsen.

Imidlertid ble pasienten reinnlagt etter seks dager på grunn av vanntynn diaré, leukopeni (leukocytter 0,4 · 10\%/l) og nøytropeni (nøytrofile leukocytter $0,3 \cdot 10^{9} /$ l). Trombocyttkonsentrasjonen var normal og $\mathrm{Hb}$-verdien stabil. Cyklofosfamid, valganciklovir og trimetoprim-sulfa kan alle gi leukopeni. Disse ble seponert, pasienten ble rehydrert og ble raskt bedre med normalisering av hematologiske verdier etter en uke. Han hadde da fått totalt to måneders behandling med cyklofosfamid, og vi valgte å endre immunsuppressiv behandling til azatioprin $50 \mathrm{mg}$ daglig som vanligvis tåles bedre enn cyklofosfamid. Ved utreise var nyrefunksjonen ytterligere bedret med serum-kreatininverdi $136 \mu \mathrm{mol} / \mathrm{l}$, og prednisolondosen var gradvis redusert til $30 \mathrm{mg}$ daglig. Pasienten ble kontrollert hyppig på poliklinikken. Det tilkom igjen forbigående problemer med leukopeni som ble normalisert etter seponering av azatioprin, valganciklovir og trimetoprim-sulfa.

På dette tidspunkt oppsto det nye komplikasjoner med hevelse i hele høyre arm, høyre side av halsen samt økte venetegninger på høyre arm og høyre del av truncus. Ultralydundersøkelse viste trombemasser i v. jugularis interna, v. subclavia og v. aksillaris.

Pasienten hadde fjernet dialysekateteret på halsen tre uker tidligere og venetrombosene antok vi oppsto sekundært til dialysekateteret. Lokal trombolytisk behandling var kontraindisert pga. økt blødningsrisiko som følge av nyresvikt, og han fikk antikoagulasjonsbehandling med fragmin 7500 enheter subkutant daglig (redusert dose pga. nyresvikt) inntil han var innstilt på warfarin. Det var nå gått litt over tre måneder siden pasienten første gang ble innlagt med akutt nyresvikt.

Etter innleggelsen for dyp venetrombose har han ikke vært hospitalisert. Nyrefunksjonen er stabil med kreatininverdier 130-140 $\mu \mathrm{mol} / \mathrm{l}$ og eGFR $45-50 \mathrm{ml} / \mathrm{min} / 1.73 \mathrm{~m}^{2}$, tilsvarende kronisk nyresvikt stadium 3. Prednisolon ble gradvis trappet ned og seponert etter til sammen 11 måneders behandlingstid. Anti-GBM- antistoff har vært negativ ved alle kontroller. Det tilkom lett stigende blodtrykksverdier tre uker etter utskrivning, og optimal blodtrykkskontroll Imål-blodtrykk 120/80 mm Hgl og antiproteinurisk behandling har vært et hovedfokus i den videre oppfølgingen. Blodtrykket er nå godt regulert med kombinasjonen angiotensinreseptorblokker og kalsiumblokker. På denne behandlingen har proteinurien avtatt fra manifest proteinuri til minimal mikroalbuminuiri lavtagende urin-albumin/kreatinin- ratio fra $138 \mathrm{mg} / \mathrm{mmol}$ til $4,4 \mathrm{mg} / \mathrm{mmol}(0-2,5 \mathrm{mg} /$ mmoll. Pasienten er nå friskmeldt og fullt arbeidsfør etter et års sykmelding.

\section{Diskusjon}

Anti-GBM-glomerulonefritt er en sjelden, men alvorlig, årsak til akutt nyresvikt. Ved affeksjon av både nyrer og lunger kalles tilstanden Goodpastures syndrom. Sykdommen medfører oftest en raskt progredierende nekrotiserende glomerulonefritt med halvmånedannelse og fare for irreversibel dialysekrevende nyresvikt. Noen ganger kan sykdommen ha et mer snikende og mindre dramatisk forløp initialt. Ved lungeblødning kan det tilkomme alvorlig respirasjonssvikt. Insidensen av anti-GBM-glomerulonefritt angis å være mindre enn en per 1000000 per år (8), og sykdommen utgjør mindre enn $20 \%$ av alle med raskt progredierende glomerulonefritt (9). Anti-GBM-sykdom kan forekomme i alle aldre (8), yngre pasienter har oftere enn eldre lungeaffeksjon med lungeblødninger i tillegg til glomerulonefritt, mens eldre oftere har isolert glomerulonefritt (10). Vår pasient hadde hostet i lengre tid før innleggelsen, men hadde ingen episoder med hemoptyse. I forløpet ble det tatt flere røntgenbilder (inklusive computertomografi) av lungene som viste litt pleuravæske bilateralt, dette ble tolket som stuving sekundært til væskeoverskudd og nyresvikt.

Patogenesen ved Goodpastures syndrom er sirkulerende antistoffer (oftest IgG) mot basalmembranen i kapillarer i glomeruli og lungealveolene. Det er ikke påvist noen sikker utløsende årsak til hvorfor antistoffene dannes. Ettersom en del pasienter ikke har lungeaffeksjon, er det antatt at epitopene i lungebasalmembranen ligger mindre tilgjengelig for antistoffene og at det ofte er en underliggende lungeskade som gjør at epitopene eksponeres. Eksempler på slik lungeskade kan være røyking og lungeinfeksjon (11). Alfa-3-kjeden i type 4-kollagen er til stede hovedsakelig i basalmembranen i nyrer og lunger og forklarer hvorfor det er disse organene som affiseres (12). Inntil $40 \%$ av pasientene har samtidig positiv ANCA (oftes anti-myeloperoksidase (MPO)-ANCA) i serum. Pasienten kan da ha symptomer på sys- temisk vaskulitt i tillegg. Det er usikkert om pasienter med både positiv anti-MPO og positiv ANCA har bedre prognose (13).

Rask diagnose og behandling er viktig for et godt behandlingsresultat ved Goodpastures syndrom. En retrospektiv studie av 71 pasienter behandlet med steroider, plasmaferese og cyklofosfamid viste at pasient- og nyreoverlevelse var henholdsvis $100 \%$ og $95 \%$ etter et år og $84 \%$ og $74 \%$ ved siste registrering (median 90 måneder) hos pasienter med initial kreatininverdi $<500 \mu \mathrm{mol} / \mathrm{l}$. Hvis pasienten derimot var dialysetrengende ved innkomst, var pasient- og nyreoverlevelse betydelig lavere (henholdsvis $65 \%$ og $8 \%$ etter et år og $36 \%$ og $5 \%$ ved langtidsoppfølging) (14). Således vil pasienter med kort sykehistorie og rask diagnose uten behov for dialyse initialt ha gode behandlingsutsikter med god langtidsprognose. Motsatt vil pasienter som har dialysetrengende nyresvikt initialt, ha liten sjanse for å bedre nyrefunksjonen og klare seg uten kronisk dialyse. Hvis initial behandling er vellykket, ses residiv av Goodpastures syndrom og anti-GBM- nefritt svært sjelden. Behandling av anti-GBM-sykdom baserer seg på plasmautskiftning for å fjerne sirkulerende antistoffer og inflammasjonsmediatorer, og immunsuppresjon med steroider og cyklofosfamid for å hindre produksjon av anti-GBM. Slik behandling skal gis til alle pasienter med lungeblødning samt til alle med akutt nyresvikt uten initialt dialysebehov. Hos pasienter uten lungeaffeksjon og med dialysetrengende nyresvikt ved innkomst må faren for behandlingskomplikasjoner vurderes opp mot muligheten for at pasienten skal gjenvinne nyrefunksjonen. Det anbefales vanligvis et behandlingsforsøk over 2-3 uker for å vurdere respons (15). Vår pasient var anurisk og dialysetrengende ved innkomst og hadde $\mathrm{i}$ utgangspunktet dårlig prognose (14). Vi valgte å gjøre et lengre behandlingsforsøk basert på kort sykehistorie, relativt ung alder, funn av tubulær nekrose og moderat mengde halvmåner (60\%) i nyrebiopsi. Den gode, dog noe sene responsen hos vår pasient, bekreftet $i$ etterkant at dette var en korrekt avgjørelse. Plasmautskiftning gis inntil anti-GBM-antistoff-titer er betydelig redusert/negativ og opphør av eventuell hemoptyse, vanligvis etter 2-3 ukers behandling. Cyklofosfamid gis vanligvis i tre måneder og kortikosteroider i 6-9 måneder $(14,15)$.

Vår pasient illustrerer viktige differensialdiagnostiske problemstillinger ved akutt nyresvikt. Forløpet illustrerer også godt betydningen av tidlig diagnostikk med immunologiske prøver hvor påvisning av antiGBM ga grunnlag for rask oppstart med målrettet behandling. Tidlig nyrebiopsi hos pasienter med akutt anurisk nyresvikt er ofte viktig når årsaken til nyreskaden og/eller behandlingsnivået ikke er tilstrekkelig avklart. Biopsien av vår pasient ble imidlertid tatt først etter knappe to uker for å unngå avbrudd i den initiale behandlingen hvor plasmautskiftning hadde en sentral rolle. 
Biopsien hos vår pasient påviste et betydelig rehabiliteringspotensial (aktiv glomerulonefritt og ingen sklerose eller fibrose) som foranlediget fortsatt plasmautskiftning og intensiv immunsuppresjon, selv om nyreprognosen initialt syntes dårlig basert på litteratur alene (14). Videre illustrerer kasuistikken også hvordan avveining av intensiv immunsuppresjon og risiko for bivirkninger av slik behandling således må ha en rasjonell begrunnelse som avveier risiko mot antatt nytte. Pasienten er i dag frisk og fullt arbeidsfør. Med normalt blodtrykk og persisterende kronisk nyresvikt stadium 3 med mikroalbuminuri er langtidsprognosen god, og faren for progredierende nyresykdom er liten $(16,17)$.

Pasienten har gitt samtykke til at artikkelen blir publisert.

\section{Per Olav Rui (f. 1972)}

er spesialist i nyresykdommer. Han arbeider som konstituert overlege ved Nyreseksjonen, Medisinsk avdeling, Haukeland universitetssykehus.

Forfatter har fylt ut ICMJE-skjemaet og oppgir ingen interessekonflikter.

\section{Einar Svarstad (f. 1948)}

er seksjonsoverlege ved Nyreseksjonen, Medisinsk avdeling, Haukeland universitetssykehus, og professor ved institutt for indremedisin, Universitetet i Bergen.

Forfatter har fylt ut ICMJE-skjemaet og oppgir følgende interessekonflikter: Han har mottatt forelesningshonorar fra Novartis, Genzyme, Amgen, Roche og Pfizer og reisestøtte til kongresser fra Genzyme, Roche og Amgen.

\section{Leif Bostad (f. 1946)}

er spesialist i patologi, seksjonsoverlege ved Avdeling for patologi,Haukeland universitetssykehus og førsteamanuensis ved Gades institutt. Han har spesialkompetanse i nyrepatologi og er leder for nyrebiopsidiagnostikken ved avdelingen og Kompetansesenteret for nefropatologi/Det Norske Nyrebiopsiregisteret. Forfatter har fylt ut ICMJE-skjemaet og oppgir ingen interessekonflikter.

\section{Bjørn Egil Vikse (f. 1977)}

er lege i spesialisering ved Medisinsk avdeling, Haukeland universitetssykehus og førsteamanuensis ved Institutt for indremedisin, Universitetet i Bergen. Han er daglig leder av Det Norske Nyrebiopsiregisteret, lokalisert til Haukeland universitetssykehus.

Forfatter har fylt ut ICMJE-skjemaet og oppgir ingen interessekonflikter.

\section{Litteratur}

1. Khan RZ, Badr KF. Endotoxin and renal function: perspectives to the understanding of septic acute renal failure and toxic shock. Nephrol Dial Transplant 1999; 14: 814-8.

2. Mohmand H, Goldfarb S. Renal dysfunction associated with intra-abdominal hypertension and the abdominal compartment syndrome. J Am Soc Nephrol 2011; 22: 615-21.

3. Praga M, González E. Acute interstitial nephritis. Kidney Int 2010; 77: 956-61

4. Rosenfeld J, Gura V, Boner G et al. Interstitial nephritis with acute renal failure after erythromycin. Br Med J (Clin Res Ed) 1983; 286: 938-9.

5. Svarstad E. Ultralyd av nyrer og urinveier. I: Ødegaard S, Gilja OH, Matre K, red. Innføring i abdominal ultrasonografi. Bergen: Fagbokforlaget, 2009: $91-101$

6. Jennette JC. Rapidly progressive crescentic glomerulonephritis. Kidney Int 2003; 63: 1164-77.

7. Kalluri R, Wilson CB, Weber $\mathrm{M}$ et al. Identification of the ? 3 chain of type IV collagen as the common autoantigen in antibasement membrane disease and Goodpasture syndrome. J Am Soc Nephrol 1995; 6: 1178-85.
8. Bolton WK. Goodpasture's syndrome. Kidney Int 1996; 50: 1753-66.

9. McLeish KR, Yum MN, Luft FC. Rapidly progressive glomerulonephritis in adults: clinical and histologic correlations. Clin Nephrol 1978. 10: 43-50.

10. Savage CO, Pusey CD, Bowman C et al. Antiglomerular basement membrane antibody mediated disease in the British Isles 1980-4. Br Med J (Clin Res Ed) 1986; 292: 301-4.

11. Donaghy M, Rees AJ. Cigarette smoking and lung haemorrhage in glomerulonephritis caused by autoantibodies to glomerular basement membrane. Lancet 1983; 2: 1390-3.

12. Derry CJ, Pusey CD. Tissue-specific distribution of the Goodpasture antigen demonstrated by 2-D electrophoresis and western blotting. Nephrol Dia Transplant 1994; 9: 355-61.

13. Rutgers A Slot $M$, van Paassen $P$ et al. Coexistence of anti-glomerular basement membrane antibodies and myeloperoxidase-ANCAs in crescentic glomerulonephritis. Am J Kidney Dis 2005 46: $253-62$

14. Levy JB, Turner AN, Rees AJ et al. Long-term outcome of anti-glomerular basement membrane antibody disease treated with plasma exchange and immunosuppression. Ann Intern Med 2001 134: 1033-42.

15. Kaplan AA, Appel GB, Pusey CD. Treatment of anti-GBM antibody (Goodpasture) disease. UpDated version 6.0, 2011

16. Sarnak MJ, Greene T, Wang X et al. The effect of a lower target blood pressure on the progression of kidney disease: long-term follow-up of the modification of diet in renal disease study. Ann Intern Med 2005; 142: 342-51

17. Hallan SI, Ritz E, Lydersen S et al. Combining GFR and albuminuria to classify CKD improves prediction of ESRD. J Am Soc Nephrol 2009: 20 : $1069-77$

Mottatt 21.3. 2011, første revisjon innsendt 16.6 2011, godkjent 26.1. 2012. Medisinsk redaktør Lars Frich/Siri Lunde.

\section{Kommentar}

\section{Alvorlig sykdom - barsk behandling}

Kombinasjonen av lungeblødning og raskt progredierende glomerulonefritt kalles ofte for pulmorenalt syndrom og kan skyldes antiGBM-sykdom (Goodpastures syndrom), ANCA-positive vaskulitter og andre autoimmune tilstander. Siden pulmorenalt syndrom er potensielt livstruende, er det viktig med rask diagnose for å redde nyrer og pasient (1). Immunologiske prøver (anti-GBM (antistoff mot glomerulusbasalmembran), ANCA (antinøytrofile cytoplasmatiske antistoffer) og ENA (extractable nuclear antigens)) bør derfor alltid rekvireres som øyeblikkelig hjelp ved utredning av akutt nyreskade med og uten lungesymptomer.

Siden den aktuelle pasienten var hypoten- siv og hadde anuri ved innkomst, var diagnosen prerenal nyresvikt eller akutt tubulær nekrose nærliggende. Begge disse årsakene til nyreskade er mye vanligere enn glomerulonefritt, og ses ofte sammen med alvorlige infeksjoner. Dersom pasienten har diurese, vil urinmikroskopi være nyttig for diagnosen. Typiske funn ved en akutt glomerulonefritt er proteinuri, hematuri, leukocytturi samt rikelig med kornede sylindre. De røde blodcellene varierer ofte i størrelse og form. Røde blodcellesylindre regnes som patognomonisk for akutt glomerulonefritt. Ved prerenal nyresvikt eller akutt tubulær nekrose vil det ikke være proteinuri eller nefrittsediment.
Ved raskt progredierende glomerulonefritt bør man vurdere om pasienten kan ha lungeblødninger, selv om pasienten ikke har hemoptyse. Anemi kan være et tegn på lungeblødning, likeledes fortetninger i lungeparenkymet på røntgen thorax. Her kunne anemien like gjerne vært sekundær til infeksjon eller overhydrering. Langvarig tørrhoste er typisk for pasienter med pulmorenalt syndrom, og ofte har pasientene hatt øvre luftveissymptomer over flere uker, slik som her. CT thorax og karbonmonoksiddiffusjonskapasitetsundersøkelse (DLCO) som er en test på om oksygentransport fra lungevev til blod er økt, kan være til hjelp for å påvise alveolær blødning. 